ISSN 1392-3196 / e-ISSN 2335-8947

Zemdirbyste-Agriculture, vol. 105, No. 3 (2018), p. 257-264

DOI 10.13080/z-a.2018.105.033

\title{
Thermophysical and chemical properties of seeds of traditional and double low cultivars of white mustard
}

\author{
Ewa ROPELEWSKA, Krzysztof J. JANKOWSKI, Piotr ZAPOTOCZNY, Bożena BOGUCKA \\ University of Warmia and Mazury in Olsztyn \\ E-mail: ewa.ropelewska@uwm.edu.pl
}

\begin{abstract}
The aim of this study was to compare the thermal, physical, mechanical and chemical properties of white mustard (Sinapis alba L.) seeds of the traditional cultivar 'Radena' and the double low cultivar 'Warta'. The selected thermal properties were determined with an analyser KD2 Pro. Cultivar 'Warta' was characterised by higher thermal conductivity $\left(0.126 \mathrm{~W} \mathrm{~m}^{-1} \mathrm{~K}^{-1}\right)$, volumetric heat capacity $\left(1.448 \mathrm{MJ} \mathrm{m}^{-3} \mathrm{~K}^{-1}\right)$ and specific heat capacity $\left(1.987 \mathrm{~kJ} \mathrm{~kg}^{-1} \mathrm{~K}^{-1}\right)$ and lower thermal resistivity $\left(793.3^{\circ} \mathrm{C} \mathrm{cm} \mathrm{W}^{-1}\right)$ than 'Radena' (thermal conductivity $0.122 \mathrm{~W} \mathrm{~m}^{-1} \mathrm{~K}^{-1}$, volumetric heat capacity $1.398 \mathrm{MJ} \mathrm{m}^{-3} \mathrm{~K}^{-1}$, specific heat capacity $1.850 \mathrm{~kJ} \mathrm{~kg}^{-1} \mathrm{~K}^{-1}$, thermal resistivity $\left.820.5^{\circ} \mathrm{C} \mathrm{cm} \mathrm{W}^{-1}\right)$. Cultivars 'Warta' and 'Radena' had identical thermal diffusivity $\left(0.087 \mathrm{~mm}^{2} \mathrm{~s}^{-1}\right)$. The values of the highest initial endothermic peaks and the last endothermic peak were determined from differential scanning calorimetry curves. The mean values of common peaks for both cultivars were determined at -17.5 , 86.0 and $402.3{ }^{\circ} \mathrm{C}$ for 'Warta', and $-16.5,69.9$ and $400.1{ }^{\circ} \mathrm{C}$ for 'Radena'. In 'Radena', an additional peak appeared at a temperature of $0.8^{\circ} \mathrm{C}$. The area under the differential scanning calorimetry curve was $1539 \mathrm{~J} \mathrm{~g}^{-1}$ for 'Warta' and $1847 \mathrm{~J} \mathrm{~g}^{-1}$ for 'Radena'. The cultivar 'Warta' was characterised by lower bulk density and true density, higher porosity and larger dimensions than the cultivar 'Radena'. The bulk density of mustard seeds was equal to $0.729 \mathrm{~g} \mathrm{~cm}^{-3}$ for 'Warta' and $0.755 \mathrm{~g} \mathrm{~cm}^{-3}$ for 'Radena', true density $1.169 \mathrm{~g} \mathrm{~cm}^{-3}$ ('Warta') and $1.203 \mathrm{~g} \mathrm{~cm}^{-3}$ ('Radena'), porosity $37.73 \%$ ('Warta') and 37.18\% ('Radena'), length $2.55 \mathrm{~mm}$ ('Warta') and $2.49 \mathrm{~mm}$ ('Radena'), width $2.29 \mathrm{~mm}$ ('Warta') and $2.27 \mathrm{~mm}$ ('Radena'). The seeds of cultivar 'Radena' had higher hardness (24.7 N), higher crude protein content (341.9 $\mathrm{g} \mathrm{kg}^{-1}$ dry matter, DM) and lower crude fat content $\left(182.9 \mathrm{~g} \mathrm{~kg}^{-1} \mathrm{DM}\right)$ than the seeds of 'Warta' $\left(21.6 \mathrm{~N}, 315.5 \mathrm{~g} \mathrm{~kg}^{-1} \mathrm{DM}\right.$ and $243.3 \mathrm{~g} \mathrm{~kg}^{-1} \mathrm{DM}$, respectively).
\end{abstract}

Key words: chemical properties, differential scanning calorimetry, physical properties, 'Radena' (traditional cultivar), thermal properties, thermogravimetric analysis, Sinapis alba, 'Warta' (double low cultivar).

\section{Introduction}

White mustard (Sinapis alba L. syn. Brassica hirta Moench) is the most cold-tolerant species of the genus Brassica. It is also characterised by high drought tolerance, high resistance to weeds and relatively high resistance to pests (Brown et al., 2005; Kaasik et al., 2014). In comparison with Indian mustard (Brassica juncea L. Czern.), white mustard is well adapted to unfavourable agronomic and environmental conditions, and its yields are $50-70 \%$ higher than those of spring oilseed rape (Jankowski et al., 2015). However, oilseed rape (Brassica napus L.), sunflower (Helianthus annuus L.) and soybean (Glycine max L. Merrill.) are the main oilseed crops in Europe. In the central, eastern and northern parts of Europe, the share of sunflower and soybeans in the crop structure is limited due to their high thermal requirements. In those parts of Europe, the predominant oilseed crop is oilseed rape, in particular its winter cultivars. However, winter oilseed rape is characterised by relatively low winter hardiness (lower than winter wheat), and the risk of freeze damage can be as high as $20 \%$ in north-eastern Poland (Jankowski et al., 2015). The risk of freeze damage to winter oilseed crops is considerably higher in countries situated further north, including Lithuania, Latvia, Estonia and Norway (Waalen et al., 2014). In those regions, spring oilseed crops of the family Brassicaceae constitute an alternative source of vegetable oil.

According to the Food and Agriculture Organization of the United Nations (FAOSTAT 2017, http://www.fao.org), the global production of mustard seeds reached $682 \mathrm{Gg}$ in 2014, of which $236 \mathrm{Gg}$ was produced in Asia (64\% in Nepal and 21\% in Myanmar), $232 \mathrm{Gg}$ in Europe (40\% in Russia and 34\% in Ukraine), and $211 \mathrm{Gg}$ in North America (94\% in Canada).

White mustard seeds have high energy value due to their relatively high content of crude fat (250 $\left.300 \mathrm{~g} \mathrm{~kg}^{-1} \mathrm{DM}\right)$ and total protein (250-370 $\left.\mathrm{g} \mathrm{kg}^{-1} \mathrm{DM}\right)$ (Schuster-Gajzágó et al., 2006; Jankowski et al., 2015). The use of white mustard seeds in food production is limited by the high content of erucic acid in seed oil

Please use the following format when citing the article:

Ropelewska E., Jankowski K. J., Zapotoczny P., Bogucka B. 2018. Thermophysical and chemical properties of seeds of traditional and double low cultivars of white mustard. Zemdirbyste-Agriculture, 105 (3): 257-264 DOI 10.13080/z-a.2018.105.033 
(55\%) (Ciubota-Rosie et al., 2013) and glucosinolates

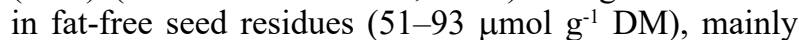
sinalbin (97-98\% of total glucosinolate content) (Jankowski et al., 2015). The oil extracted from the seeds of traditional white mustard cultivars contains fatty acids with health benefits, including oleic acid (12\%), linoleic acid (12\%) and linolenic acid (9\%) (Ciubota-Rosie et al., 2013). White mustard and Indian mustard were the last economically important crops of the genus Brassica to be deprived of antinutritional compounds. In 1974, the first double low oilseed rape cultivar ('Tower') with a low content of erucic acid and glucosinolate was developed by the University of Manitoba, Canada. Three years later, the first double low cultivar ('Candle') of turnip rape (Brassica rape L.) was developed by the Agriculture and Agri-Food Canada Department of the Canadian government (Canola Council of Canada, 2017). In 2002, the Saskatchewan Wheat Pool, Canada introduced the cultivars 'Arid' and 'Amulet' of Indian mustard (Potts et al., 2003). The world's first double low white mustard (Sinapis alba L.) cultivar 'Warta' characterised by an absence of erucic acid and reduced glucosinolate content was registered in 2012 in Poland (Piętka et al., 2014). The oil from white mustard seeds (double low) contains $62-68 \%$ oleic acid, $12-15 \%$ linoleic acid and $11-14 \%$ linolenic acid. It is a more abundant source of n-3 polyunsaturated fatty acids (PUFAs), and it is characterised by a more desirable n-6:n-3 PUFA ratio (1:1) than rapeseed oil, which contributes to the high nutritional value of white mustard oil (Piętka et al., 2014). A good knowledge of the properties, such as specific heat capacity, thermal conductivity, thermal diffusivity, density and porosity is essential for designing cooking, heating, drying, sterilization, cooling, refrigeration and thawing equipment, optimizing transport and storage conditions. Additionally, specific heat capacity, thermal conductivity and thermal diffusivity are important for determining the sensory quality of food products (Ikegwu, Ezeh, 2012; Mahapatra et al., 2013). Thermal conductivity, specific heat capacity and thermal diffusivity parameters are important determinants of heat transfer characteristics (Sirisomboon, Posom, 2012; Jibril et al., 2016). Furthermore, knowledge of the physical properties (bulk density, true density, porosity, surface area, length and width) of food products and mechanical behaviour under compression is also required for designing processing equipment and planning the optimal conditions for the harvesting, handling, sorting, storage and processing (heating, drying and cooling) of seeds (Tavakoli et al., 2009 a; b; Sangamithra et al., 2016).

The aim of this study was to compare the thermal, physical, mechanical and chemical properties of seeds of two white mustard cultivars: (i) a traditional cultivar with a high content of erucic acid and glucosinolates ('Radena') and (ii) a double low cultivar with a reduced content of erucic acid and glucosinolates ('Warta'). Thermal conductivity, thermal resistivity, volumetric heat capacity and thermal diffusivity were determined, and differential scanning calorimetry (DSC) and thermogravimetric analysis (TGA) curves were plotted. The bulk density, true density, porosity, geometric parameters (linear dimensions, surface area and shape factors), mechanical properties (hardness, displacement and area under the force-displacement graph) and chemical properties (crude protein and crude fat) of the analysed seeds were determined.

\section{Materials and methods}

The experiment was performed with the seeds of two white mustard (Sinapis alba L.) cultivars: 1) 'Radena', a traditional cultivar with a high content of erucic acid and glucosinolates, and 2) 'Warta', a double low cultivar with a reduced content of erucic acid and glucosinolates. The seeds of both white mustard cultivars were obtained from a field experiment carried out in 2016 at the Agricultural Experimental Station in Bałcyny (N 5335'49", E 1951'20.3") owned by the University of the Warmia and Mazury in Olsztyn, Poland. The experiment was established on a Haplic Luvisol ( $L V-h a)$ originating from boulder clay (WRB, 2014). Plot size was $15 \mathrm{~m}^{2}(1.5 \times 10 \mathrm{~m})$.

The seeds of white mustard cultivars 'Radena' and 'Warta' were sown in early April with a row seeder at 120 seeds $\mathrm{m}^{-2}$, with a distance of $19 \mathrm{~cm}$ between rows, at a depth of $2-3 \mathrm{~cm}$. The plants were fertilized with $120 \mathrm{~kg} \mathrm{ha}^{-1} \mathrm{~N}\left(80 \mathrm{~kg} \mathrm{ha}^{-1} \mathrm{~N}\right.$ before sowing and $40 \mathrm{~kg} \mathrm{ha}^{-1}$ at the beginning of flower bud formation) as ammonium nitrate $(34 \% \mathrm{~N}), 60 \mathrm{~kg} \mathrm{ha}^{-1} \mathrm{P}_{2} \mathrm{O}_{5}$ (pre-sowing) in enriched superphosphate $\left(40 \% \mathrm{P}_{2} \mathrm{O}_{5}\right)$ and $100 \mathrm{~kg} \mathrm{ha}^{-1} \mathrm{~K}_{2} \mathrm{O}$ (presowing) in potash salt $\left(60 \% \mathrm{~K}_{2} \mathrm{O}\right)$. During the growing season, weeds and pests were controlled in accordance with integrated pest management standards (OJEC, 2009). White mustard was harvested at physiological maturity (late July) with a small-plot harvester.

The thermal properties of mustard seeds were determined with an analyser KD2 Pro with the dual-needle sensor SH-1 (Decagon Devices Inc., USA). The values of thermal conductivity, thermal resistivity, volumetric heat capacity and thermal diffusivity were determined. The measurements were performed in five replicates for each cultivar. Therefore, the seeds (about $70 \mathrm{~g}$ ) were placed in a $100 \mathrm{~cm}^{3}$ beakers ( 5 beakers for each cultivar), and the sensor was inserted into the bulk mass of sample. For each beaker, one measurement was performed.

The differential scanning calorimeter / thermogravimetric analyser STA 449 F1 Jupiter ${ }^{\circledR}$ (Netzsch-Gerätebau GmbH, Germany) was used to plot differential scanning calorimetry (DSC) and thermogravimetric analysis (TGA) curves. Thermal properties were measured in a temperature range of -30 to $500^{\circ} \mathrm{C}$, with a heating rate of $10 \mathrm{~K} \mathrm{~min}^{-1}$, $20 \mathrm{ml} \mathrm{min}^{-1}$ gas flow, in a helium atmosphere. The device was calibrated using mercury, water, gallium, indium, tin, bismuth and zinc as standards. The seeds were ground in a laboratory grinder and homogenized before measurement. Representative samples of approximately 15 milligrams each were placed in an alumina crucible. The measurements were carried out in three replicates (three crucibles with 15 milligrams of ground seeds for each cultivar).

The moisture content $(\%)$ of seeds was measured based on the International Rules for Seed Testing (ISTA 2013, https://www.seedtest.org). Bulk density, $\rho_{h}\left(\mathrm{~g} \mathrm{~cm}^{-3}\right)$, was determined according to the standard EN ISO 79713:2009 (Cereals - Determination of bulk density, called mass per hectolitre. Part 3: Routine method). A $100 \mathrm{~cm}^{3}$ graduated glass cylinder was used. The weight of samples was about $70 \mathrm{~g}$. True density, $\rho_{t}\left(\mathrm{~g} \mathrm{~cm}^{-3}\right)$, was determined with a $100 \mathrm{~cm}^{3}$ glass pycnometer (sample weight was about $5 \mathrm{~g}$ ) based on the standard EN 1097-6:2013 (Tests for mechanical and physical properties of aggregates. Determination of particle density and water absorption). 
Mass measurements were read to the nearest $0.001 \mathrm{~g}$ using an electronic balance (RADWAG, WPS 4000/C/2, Poland). Porosity (\%) was calculated using the equation: $\varepsilon=\frac{\rho_{t}-\rho_{b}}{\rho_{t}} \times 100(\%)$, where $\varepsilon$ is porosity, $\rho_{t}-$ true density, $\rho_{b}-$ bulk density. replicates.

The measurements were performed in five

Images of white mustard seeds were acquired with the photo flatbed scanner Perfection 4490 (Epson, UK) and the scanning software SilverFast Ai Studio Epson, version 6.6.1r6 (LaserSoft Imaging Inc., USA). Five images of around 200 seeds each (a total of 1000 seeds) were acquired for each cultivar. Image analysis was performed with the use of software MaZda, version 4.6 (Łódź University of Technology, Institute of Electronics, Poland). Based on obtained images, the geometric parameters (linear dimensions, surface area, shape factors) were determined.

The mechanical properties of mustard seeds were determined using the texture analyser TA.HD plus (Stable Micro Systems, UK). The displacement of measurements was equal to $40 \%$ of height, initial height was $2.1 \mathrm{~mm}$ and test speed $1.8 \mathrm{~mm} \mathrm{~min}^{-1}$. The measurements were performed for 35 seeds of cultivar 'Warta' and 35 seeds of cultivar 'Radena'. Based on one measurement (for one seed), displacement $(\mathrm{mm})$, hardness $(\mathrm{N})$ and area under the force-displacement graph $\left(\mathrm{N} \mathrm{mm}^{-1}\right)$ were determined.

The content of crude protein was determined by the Kjeldahl method (sample weight $-1 \mathrm{~g}$ ), and crude fat content was determined by the Soxhlet method (sample weight $-60 \mathrm{~g})$. The measurements were performed in three replicates (three samples of $1 \mathrm{~g}$ of seeds for measurements of content of crude protein and three samples of $60 \mathrm{~g}$ of seeds for measurements of crude fat content) for each cultivar.

Statistically significant differences between the mean values of selected thermal, physical, mechanical and chemical parameters of the seeds of white mustard cultivars 'Warta' and 'Radena' were determined. Due to the specific character of the data and the size of the experimental groups, the results were processed statistically in three steps: (i) analysis of normal distribution of variables, (ii) analysis of the homogeneity of variance, and, depending on the results obtained in the first two steps, (iii) determination of the significance of differences between mean values in Student's $t$-test or the Mann-Whitney $U$ test. All analyses were performed at a significance level of $P \leq 0.05$. The Shapiro-Wilk test and the Lilliefors test were used to check whether the variables were normally distributed. The homogeneity of variance was analysed by Levene's test and the BrownForsythe test.

\section{Results and discussion}

The mean values of thermal properties, including thermal conductivity, thermal resistivity, volumetric heat capacity, specific heat capacity and thermal diffusivity of the analysed mustard seeds are presented in Table 1.

Table 1. Thermal properties of white mustard seeds measured with an analyser KD2 Pro

\begin{tabular}{ccccc}
\hline Cultivar & $\begin{array}{c}\text { Thermal conductivity } \\
\mathrm{W} \mathrm{m}^{-1} \mathrm{~K}^{-1}\end{array}$ & $\begin{array}{c}\text { Thermal resistivity } \\
{ }^{\circ} \mathrm{Cm} \mathrm{W}^{-1}\end{array}$ & $\begin{array}{c}\text { Volumetric heat } \\
\text { capacity } \\
\mathrm{MJ} \mathrm{m}^{-3} \mathrm{~K}^{-1}\end{array}$ & $\begin{array}{c}\text { Specific heat } \\
\text { capacity } \\
\mathrm{kJ} \mathrm{kg}^{-1} \mathrm{~K}^{-1}\end{array}$ \\
\hline Warta & $0.126 \mathrm{a}$ & $793.3 \mathrm{a}$ & $1.448 \mathrm{a}$ & $1.987 \mathrm{a}$ \\
Radena & $0.122 \mathrm{a}$ & $820.5 \mathrm{a}$ & $1.398 \mathrm{a}$ & $1.850 \mathrm{~b}$ \\
\hline
\end{tabular}

Note. Letters a and b denote homogeneous groups, $P \leq 0.05$; values are mean of five replicates (about $70 \mathrm{~g}$ of seeds in a $100 \mathrm{~cm}^{3}$ beaker in each replicate) for each cultivar.

The cultivar 'Warta' was characterised by higher values of thermal conductivity $\left(0.126 \mathrm{~W} \mathrm{~m}^{-1} \mathrm{~K}^{-1}\right)$, volumetric heat capacity $\left(1.448 \mathrm{MJ} \mathrm{m}^{-3} \mathrm{~K}^{-1}\right)$ and specific heat capacity $\left(1.987 \mathrm{~kJ} \mathrm{~kg}^{-1} \mathrm{~K}^{-1}\right)$, and lower value of thermal resistivity $\left(793.3^{\circ} \mathrm{C} \mathrm{cm} \mathrm{W}^{-1}\right)$ than the 'Radena'. Significant differences in the values of thermal conductivity, volumetric heat capacity and thermal resistivity were not observed between the cultivars. Two homogenous groups were identified for specific heat capacity. Cultivars 'Warta' and 'Radena' had identical values of thermal diffusivity $(0.087$ $\mathrm{mm}^{2} \mathrm{~s}^{-1}$ ). Information about the thermal conductivity of other oil seeds can be found in the literature. According to Kocabiyik and Tezer (2007), the thermal conductivity of rapeseeds ranged from 0.214 to $0.292 \mathrm{~W} \mathrm{~m}^{-1} \mathrm{~K}^{-1}$. Jian et al. (2012) determined the thermal conductivity of double low seeds at $0.087 \mathrm{~W} \mathrm{~m}^{-1}{ }^{\circ} \mathrm{C}^{-1}$. According to İnce et al. (2008), the thermal conductivity of corn seeds ranged from 0.119 to $0.247 \mathrm{~W} \mathrm{~m}^{-1}{ }^{\circ} \mathrm{C}^{-1}$, of soybeans - from 0.098 to $0.226 \mathrm{~W} \mathrm{~m}^{-1}{ }^{\circ} \mathrm{C}^{-1}$, of sunflower seeds - from 0.093 to $0.209 \mathrm{~W} \mathrm{~m}^{-1}{ }^{\circ} \mathrm{C}^{-1}$. In the above study, specific heat capacity was determined at 1.4868 to $2.4224 \mathrm{~kJ} \mathrm{~kg}^{-1}{ }^{\circ} \mathrm{C}^{-1}$ for corn seeds, 1.3934 to $3.1976 \mathrm{~kJ} \mathrm{~kg}^{-1}{ }^{\circ} \mathrm{C}^{-1}$ for soybeans and 0.8649 to $1.9302 \mathrm{~kJ} \mathrm{~kg}^{-1}{ }^{\circ} \mathrm{C}^{-1}$ for sunflower seeds, whereas thermal diffusivity was determined at $1.111 \times 10^{-7}-1.371 \times$ $10^{-7} \mathrm{~m}^{2} \mathrm{~s}^{-1}$ for corn seeds, $8.268 \times 10^{-8}-1.496 \times 10^{-7} \mathrm{~m}^{2} \mathrm{~s}^{-1}$ for soybeans and $2.325 \times 10^{-7}-3.695 \times 10^{-7} \mathrm{~m}^{2} \mathrm{~s}^{-1}$ for sunflower seeds. According to Darvishi et al. (2012), the thermal conductivity of black sunflower seeds ranged from 0.079 to $0.134 \mathrm{~W} \mathrm{~m}^{-1} \mathrm{~K}^{-1}$, specific heat capacity - from 2.55 to $8 \mathrm{~kJ} \mathrm{~kg}^{-1} \mathrm{~K}^{-1}$, and thermal diffusivity - from $4.63 \times 10^{-8}$ to $7.64 \times 10^{-8} \mathrm{~m}^{2} \mathrm{~s}^{-1}$.

The DSC curves for white mustard seeds of cultivars 'Warta' and 'Radena' are presented in Figure 1, and their characteristics are presented in Table 2. The TGA curves for cultivars 'Warta' and 'Radena' are shown in Figure 1.

Both curves had a similar course, but total mass loss was higher in the TGA curve for 'Warta' seeds (Table 2).

The two highest endothermic peaks were observed for the seeds of 'Warta'. In the seeds of 'Radena', three distinct endothermic peaks were identified. An additional peak appeared at a temperature of $0.8^{\circ} \mathrm{C}$ in 'Radena', but not in 'Warta'. The values of the last endothermic peaks were also determined. The cultivar 'Warta' was characterised by a lower value of the first peak and a higher temperature of successive common peaks, which points to slower thermal decomposition. The area under the DSC curve was larger in 'Radena', which may be associated with the presence 

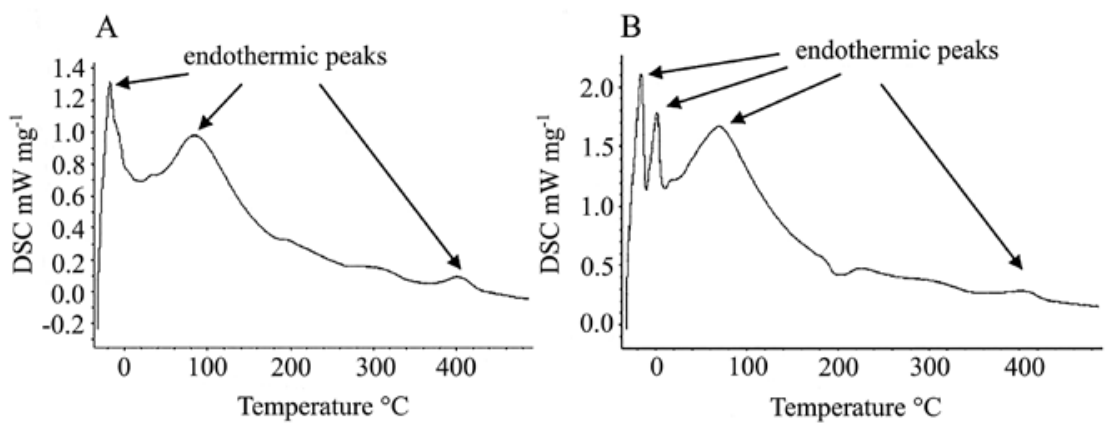

$\mathrm{C}$

$\mathrm{D}$
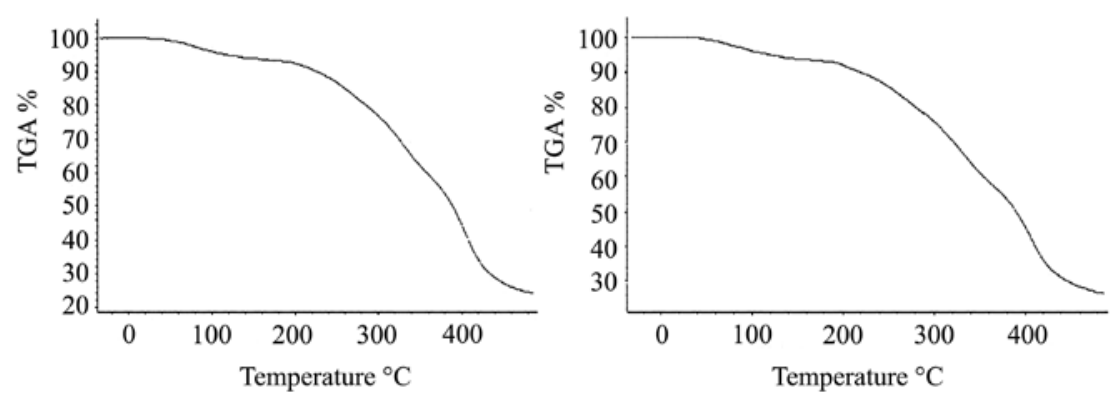

Figure 1. Differential scanning calorimetry (DSC) curves of white mustards seeds (A - 'Warta', B - 'Radena') and thermogravimetric analysis (TGA) curves (C - 'Warta', D - 'Radena')

Table 2. Thermal properties of white mustard seeds measured with a simultaneous analyser STA449 F1 Jupiter

\begin{tabular}{|c|c|c|c|c|c|c|}
\hline Cultivar & $\begin{array}{c}1^{\text {st }} \\
\text { endothermic peak } \\
{ }^{\circ} \mathrm{C}\end{array}$ & $\begin{array}{c}2^{\text {nd }} \\
\text { endothermic peak } \\
{ }^{\circ} \mathrm{C}\end{array}$ & $\begin{array}{c}3^{\text {rd }} \\
\text { endothermic peak } \\
{ }^{\circ} \mathrm{C} \\
\end{array}$ & $\begin{array}{c}\text { Last } \\
\text { endothermic peak } \\
{ }^{\circ} \mathrm{C}\end{array}$ & $\begin{array}{c}\text { Area } \\
\text { under DSC curve } \\
\mathrm{J} \mathrm{g}^{-1} \\
\end{array}$ & $\begin{array}{c}\text { Mass } \\
\text { loss } \\
\%\end{array}$ \\
\hline Warta & $-17.5 \mathrm{a}$ & - & $86.0 \mathrm{a}$ & $402.3 \mathrm{a}$ & $1539 \mathrm{a}$ & $76.48 \mathrm{a}$ \\
\hline Radena & $-16.5 \mathrm{a}$ & 0.8 & $69.9 \mathrm{~b}$ & $400.1 \mathrm{a}$ & $1847 \mathrm{~b}$ & $74.09 \mathrm{a}$ \\
\hline
\end{tabular}

Note. DSC - differential scanning calorimetry; letters a and $\mathrm{b}$ denote homogeneous groups, $P \leq 0.05$, values are mean of three replicates (approximately 15 milligrams of ground seeds in each replicate) for each cultivar.

of an additional second peak and higher protein content (Table 2). Statistically significant differences between the cultivars were observed for the third endothermic peak and the area under the DSC curve.

The moisture content of white mustard seeds of both cultivars was equal to $6 \%$. The bulk density of seeds ranged from 0.729 to $0.755 \mathrm{~g} \mathrm{~cm}^{-3}$, and true density - from 1.169 to $1.203 \mathrm{~g} \mathrm{~cm}^{-3}$. The measured parameters were lower in the seeds of cultivar 'Warta'. The porosity of seeds was higher (37.73\%) in 'Warta' than in 'Radena' $(37.18 \%)$. The only significant difference between the cultivars was observed in the mean values of bulk density (Table 3, Fig. 2). In a study by Grewal and Singh (2016), the bulk density of seeds of two mustard cultivars was determined at $0.906-0.798 \mathrm{~g} \mathrm{~cm}^{-3}$ (cultivar PBR-91) and 0.890-0.785 $\mathrm{g} \mathrm{cm}^{-3}$ (cultivar RLC-1) as the moisture content of both cultivars increased from $6 \%$ to $18 \%$ (wet basis). True density was $1.199-0.924$ and $1.275-0.954 \mathrm{~g} \mathrm{~cm}^{-3}$, and porosity was $24.43-13.63 \%$ and $30.19-17.77 \%$ for cultivars PBR-91 and RLC-1, respectively. Damian (2014) reported higher porosity values of mustard seeds in the range of $46.32 \%$ to $47.97 \%$ for the moisture content of $7.0 \%$ and $15.99 \%$ (dry basis), respectively.

The cultivar 'Warta' was characterised by higher values of linear dimensions (length and width), surface area and selected shape factors (profile specific perimeter and folding factor). However, seed roundness was lower in 'Warta' (Table 3). Seed width did not differ significantly between the cultivars. Statistically significant differences were observed in the remaining parameters, and two homogenous groups were identified. Seed length was determined at 2.55 and $2.49 \mathrm{~mm}$, and seed width was determined at $2.29 \mathrm{~mm}$ for 'Warta' and $2.27 \mathrm{~mm}$ for 'Radena'. In the work of Mieszkalski et al. (2015), the length of white mustard seeds ranged from 2.49 to $2.53 \mathrm{~mm}$ and seed width - from 2.3 to $2.34 \mathrm{~mm}$. According to Damian (2014), the size of mustard seeds

Table 3. Physical and geometrical properties of white mustard seeds

\begin{tabular}{|c|c|c|c|c|c|c|c|c|c|}
\hline Cultivar & $\begin{array}{c}\text { Bulk } \\
\text { density } \\
\mathrm{g} \mathrm{cm}^{-3}\end{array}$ & $\begin{array}{c}\text { True } \\
\text { density } \\
\mathrm{g} \mathrm{cm}^{-3}\end{array}$ & $\begin{array}{c}\text { Porosity } \\
\%\end{array}$ & $\begin{array}{l}\text { Length } \\
\mathrm{mm}\end{array}$ & $\begin{array}{l}\text { Width } \\
\text { mm }\end{array}$ & $\begin{array}{c}\text { Surface } \\
\text { area } \\
\mathrm{mm}^{2}\end{array}$ & $\begin{array}{c}\text { Profile } \\
\text { specific } \\
\text { parameter }\end{array}$ & $\begin{array}{c}\text { Folding } \\
\text { factor }\end{array}$ & Roundness \\
\hline Warta & $0.729 \mathrm{a}$ & $1.169 \mathrm{a}$ & $37.73 \mathrm{a}$ & $2.55 \mathrm{a}$ & $2.29 \mathrm{a}$ & $4.75 \mathrm{a}$ & $20.90 \mathrm{a}$ & $2.69 \mathrm{a}$ & $0.25 \mathrm{a}$ \\
\hline Radena & $0.755 \mathrm{~b}$ & $1.203 \mathrm{a}$ & $37.18 \mathrm{a}$ & $2.49 \mathrm{~b}$ & $2.27 \mathrm{a}$ & $4.62 \mathrm{~b}$ & $20.50 \mathrm{~b}$ & $2.68 \mathrm{~b}$ & $0.26 \mathrm{~b}$ \\
\hline
\end{tabular}

Note. Letters a and $\mathrm{b}$ denote homogeneous groups, $P \leq 0.05$; values are mean of five replicates for physical properties: bulk density (about $70 \mathrm{~g}$ of seeds in each replicate), true density (about $5 \mathrm{~g}$ of seeds in each replicate), porosity (calculated based on five values of bulk density and true density) and 1000 seeds for the geometrical properties for each cultivar. 

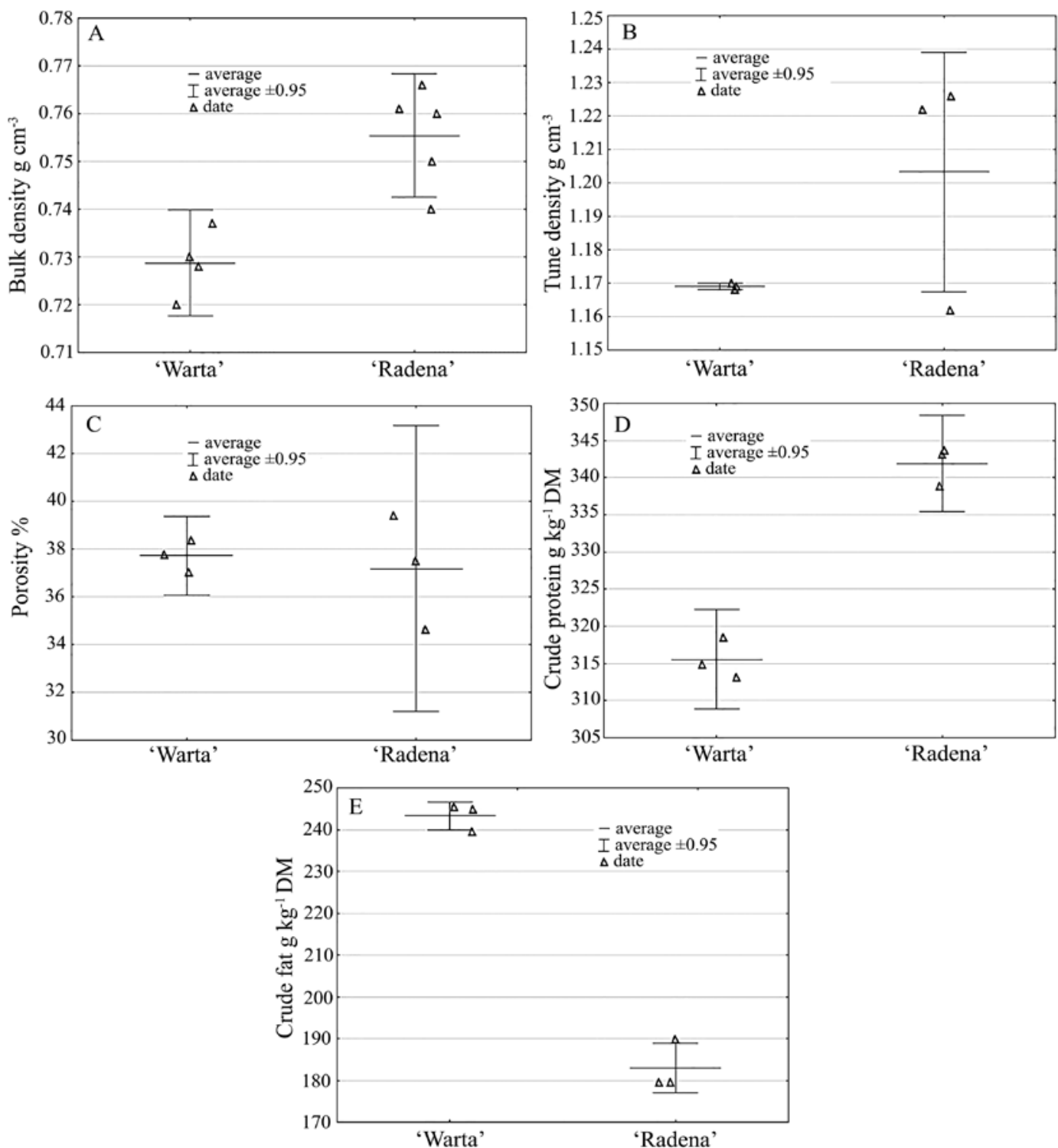

Figure 2. Values of bulk density (A), true density (B), porosity (C), crude protein content (D) and crude fat content (E) of white mustard seeds

ranged from 2.88 to $3.04 \mathrm{~mm}$ for moisture content of $7-15.99 \%$. For comparison, the rapeseeds are closer to the size and shape of white mustard seeds. Ropelewska et al. (2017) analysed selected geometric properties of rapeseeds and found that their values were smaller than those for white mustard seeds. Rapeseeds were characterised by a length of $1.93-2.03 \mathrm{~mm}$, width of $1.67-1.77 \mathrm{~mm}$, surface area of $2.75-3.07 \mathrm{~mm}$ and profile specific perimeter of $15.79-16.65 \mathrm{~mm}$.

The seeds of cultivar 'Radena' were characterised by higher hardness $(24.7 \mathrm{~N})$ than the seeds of 'Warta'
$(21.6 \mathrm{~N})$. However, displacement and the area under the force-displacement graph were lower in 'Radena'. The observed differences were not statistically significant (Table 4). The hardness of rapeseeds was determined at $11.71 \mathrm{~N}$ by Izli et al. (2009) and at $11.50-12.00 \mathrm{~N}$ by Ropelewska et al. (2017).

The chemical properties of mustard seeds are presented in Table 4. The cultivar 'Warta' was characterised by lower crude protein content and higher crude fat content than the 'Radena'. The differences between mean values were statistically significant for

Table 4. Mechanical and chemical properties of white mustard seeds

\begin{tabular}{cccccc}
\hline Cultivar & $\begin{array}{c}\text { Hardness } \\
\mathrm{N}\end{array}$ & $\begin{array}{c}\text { Displacement } \\
\mathrm{mm}\end{array}$ & $\begin{array}{c}\text { Area under force- } \\
\text { displacement graph } \\
\mathrm{N} \mathrm{mm}^{-1}\end{array}$ & $\begin{array}{c}\text { Crude protein } \\
\mathrm{g} \mathrm{kg}^{-1} \mathrm{DM}\end{array}$ & $\begin{array}{c}\text { Crude fat } \\
\mathrm{g} \mathrm{kg}^{-1} \mathrm{DM}\end{array}$ \\
\hline Warta & $21.6 \mathrm{a}$ & $0.22 \mathrm{a}$ & $2.50 \mathrm{a}$ & $315.5 \mathrm{a}$ & $243.3 \mathrm{a}$ \\
Radena & $24.7 \mathrm{a}$ & $0.19 \mathrm{a}$ & $2.43 \mathrm{a}$ & $341.9 \mathrm{~b}$ & $182.9 \mathrm{~b}$ \\
\hline
\end{tabular}

Note. Letters a and b denote homogeneous groups, $P \leq 0.05$; values are mean of 35 seeds of cultivar 'Warta' and 35 seeds of cultivar 'Radena' for mechanical properties and three replicates (three samples of $1 \mathrm{~g}$ of seeds for measurements of content of crude protein and three samples of $60 \mathrm{~g}$ of seeds for measurements of crude fat content) for each cultivar; DM - dry matter. 
both parameters, and two homogenous groups were identified (Table 4, Fig. 2).

The results of this study may have practical applications in the food processing industry. Knowledge of the thermal properties of mustard seeds can be used for selecting the appropriate process parameters. The amount of energy required to change a food product's temperature can be determined based on the values of specific heat capacity. Thermal conductivity and thermal diffusivity have to be determined to estimate the rate of heat transfer (Ikegwu, Ezeh, 2012). Thermal conductivity determines the ability of a material to conduct heat (Sahin, Sumnu, 2006). Thermal diffusivity data can be used to determine the duration of thermal processes (Mahapatra et al., 2013). The thermal properties of food products can be measured directly, with the use of different devices and techniques such as an analyser KD2 Pro and thermal analysis (Lever et al., 2014; Barnwal et al., 2015; Perussello et al., 2015), and indirectly using mathematical calculations based on the chemical composition (water, protein, fat, carbohydrates, fibre and ash), temperature and structure of the analysed material (Choi, Okos, 1986; Sahin, Sumnu, 2006; Wang et al., 2008; Carson, 2015). Therefore, some of our findings can be used for mathematical modelling. The physical properties of seeds, determined in our study, can be used in practice by professionals involved in seed processing operations, food engineers and scientists. Bulk density data can be useful for determining the parameters of containers and packages during storage and transport. Porosity is important for determining the flow rates of air and liquids between seeds during drying, heating and cooling, as well as fan and pump performance. The dimensions and surface area of seeds are important when analysing heat transfer through a material, and when estimating the rate and time of drying, heating and cooling operations (Wilhelm et al., 2004).

Double low cultivar 'Warta' had the higher values of length, width and surface area of seeds. Therefore, seed producers may prefer this cultivar. The seeds of 'Warta' were also more thermally stable. Among the mechanical features, 'Warta' was characterised by lower hardness of seeds, which may facilitate the processing of seeds. Considering the chemical parameters of white mustard seeds, double low cultivar 'Warta', due to higher crude fat content, as well as absence of erucic acid and reduced glucosinolate content, is desirable for fat production plants. Whereas the traditional cultivar 'Radena' had a higher protein content. Therefore, the seeds of 'Radena' are perfectly suitable for the production of mustard.

The thermal, physical, mechanical and chemical properties of seeds can be used in further research for seed classification and discriminant analysis to distinguish between double low and traditional cultivars of white mustard. The available literature provides information on the use of seed characteristics to discriminate between cultivars. The randomly amplified polymorphic DNA (RAPD) method was applied by Mailer et al. (1994) to classify rapeseed cultivars from various breeding programs. Distance-based discriminant analysis and neural networks were used by Zou et al. (2011) for the identification of rapeseed cultivars. The cited authors achieved $100 \%$ accuracy. In a study by Kurtulmuş and Ünal
(2015), the discrimination accuracy of rapeseed cultivars reached 99.24\%. Zapotoczny et al. (2016) distinguished the groups of fenugreek seeds under various cultivation regimes based on seed parameters. Ropelewska et al. (2017) distinguished winter, spring, open-pollinated and hybrid rapeseed cultivars using discriminant analysis and neural networks with total accuracy of approximately 75-92\%. Geetha and Balamurugan (2011) discriminated between mustard cultivars based on the nature of seed protein. In addition to cultivar, seed parameters are also affected by various agronomic factors such as the use of fertilization and crop protection agents, and seeding dates and rates (Talafih et al., 2007).

\section{Conclusions}

1. The differences in the thermal properties of cultivars 'Radena' and 'Warta' were statistically significant for specific heat capacity. The cultivar 'Warta' was characterised by higher values of specific heat capacity $\left(1.987 \mathrm{~kJ} \mathrm{~kg}^{-1} \mathrm{~K}^{-1}\right)$ than 'Radena' $\left(1.850 \mathrm{~kJ} \mathrm{~kg}^{-1}\right.$ $\left.\mathrm{K}^{-1}\right)$. Thermal decomposition was slower in the seeds of 'Warta', as demonstrated by the higher temperature of peaks on the differential scanning calorimetry (DSC) curve than in the seeds of 'Radena'. The area under the DSC curve was lower for 'Warta' (1539 $\left.\mathrm{J} \mathrm{g}^{-1}\right)$ than for 'Radena' (1847 J g $\left.{ }^{-1}\right)$.

2. Among the physical properties, bulk density was statistically significantly lower in 'Warta' (0.729 $\left.\mathrm{g} \mathrm{cm}^{-3}\right)$ than in 'Radena' $\left(0.755 \mathrm{~g} \mathrm{~cm}^{-3}\right)$. The cultivar 'Warta' was characterised by statistically significantly higher values of geometric parameter, e.g., length $(2.55$ $\mathrm{mm})$, surface area $(4.75 \mathrm{~mm})$ than 'Radena' (length 2.49 $\mathrm{mm}$, surface area $4.62 \mathrm{~mm})$.

3. The differences in the mechanical properties (hardness, displacement and area under the forcedisplacement graph) of both cultivars ('Warta' and 'Radena') were not statistically significant.

4. The seeds of cultivar 'Warta' had statistically significantly lower crude protein content $\left(315.5 \mathrm{~g} \mathrm{~kg}^{-1}\right.$ DM) than 'Radena' (341.9 $\mathrm{g} \mathrm{kg}^{-1} \mathrm{DM}$ ) and higher crude fat content (243.3 $\left.\mathrm{g} \mathrm{kg}^{-1} \mathrm{DM}\right)$ than the 'Radena' (182.9 $\left.\mathrm{g} \mathrm{kg}^{-1}\right)$.

\section{Acknowledgments}

The results presented in this paper were obtained as part of a comprehensive study financed by the University of Warmia and Mazury in Olsztyn (grants Nos 20.610.020-300 and 16.610.001-300) and by the National Science Centre in Poland (grant No. 2015/17/B/ NZ9/03601).

Received 16082017 Accepted 17052018

\section{References}

1. Barnwal P., Singh K. K., Sharma A., Choudhary A. K., Saxena S. N. 2015. Influence of pin and hammer mill on grinding characteristics, thermal and antioxidant properties of coriander powder. Journal of Food Science and Technology, 52 (12): 7783-7794. https://doi.org/10.1007/s13197-015-1975-0 
2. Brown J., McCaffrey J. P., Brown D. A., Harmon B. L., Davis B. L. 2005. Yield reduction in Brassica napus, B. rapa, B. juncea, and Sinapis alba caused by flea beetle (Phyllotreta cruciferae (Goeze) (Coleoptera: Chrysomelidae)) infestation in Northern Idaho. Journal of Economic Entomology, 97 (5): 1642-1647. https://doi.org/10.1603/0022-0493-97.5.1642

3. Canola Council of Canada. 2017. The history of canola. http://www.canolacouncil.org/oil-and-meal/what-iscanola/the-history-of-canola.

4. Carson J. K. 2015. Thermal conductivity measurement and prediction of particulate foods. International Journal of Food Properties, 18: 2840-2849.

https://doi.org/10.1080/10942912.2015.1016576

5. Choi Y., Okos M. R. 1986. Effects of temperature and composition on the thermal properties of foods. LeMaguer M., Jelen P. (eds). Food engineering and process applications, 1. Elsevier Applied Science, p. 93-101.

6. Ciubota-Rosie C., Macoveanu M., Fernández C. M., Ramos M. J., Pérez A., Moreno A. 2013. Sinapis alba seed as a prospective biodiesel source. Biomass and Bioenergy, 51: 83-90.

https://doi.org/10.1016/j.biombioe.2013.01.008

7. Damian C. 2014. Physical properties of mustard seeds (Sinapis alba L.). Lucrări Ştiinţifice - Seria Zootehnie, 61: 39-44.

8. Darvishi H., Azadbakht M., Asl A. R. 2012. Measurement of thermal conductivity, specific heat, thermal diffusivity and diffusivity of black sunflower seeds. International Journal of Agricultural and Food Science, 2 (3): 96-99.

9. Geetha V. V., Balamurugan P. 2011. SDS PAGE electrophoresis in mustard cultivars. International Journal of Agricultural Research, 6: 437-443.

https://doi.org/10.3923/ijar.2011.437.443

10. Grewal P. S., Singh A. K. 2016. Moisture dependent physical and frictional properties of mustard seeds. International Journal of Engineering Development and Research, 4 (4): 464-470.

11. Ikegwu O. J., Ezeh C. Q. 2012. Thermal properties of Kerstingiella geocarpa seeds as influenced by moisture content. Nigerian Food Journal, 30 (2): 100-105. https://doi.org/10.1016/S0189-7241(15)30042-4

12. İnce R., Güzel E., İnce A. 2008. Thermal properties of some oily seeds. Journal of Agricultural Machinery Science, 4 (4): 399-405.

13. Izli N., Unal H., Sincik M. 2009. Physical and mechanical properties of rapeseed at different moisture content. International Agrophysics, 23: 137-145.

14. Jankowski K. J., Budzyński W. S., Kijewski Ł., Zając T. 2015. Biomass quality of Brassica oilseed crops in response to sulfur fertilization. Agronomy Journal, 107 (4): 1377-1391. https://doi.org/10.2134/agronj14.0386

15. Jian F., Jayas D. S., White N. D. G. 2012. Thermal conductivity, bulk density, and germination of a canola variety with high oil content under different temperatures, moisture contents, and storage periods. ASABE, 55 (5): 1837-1843. https://doi.org/10.13031/2013.42336

16. Jibril A. N., Yadav K. C., Binni M. I., Kabir M. H. 2016. Study on effect of moisture content on thermal properties of bambara groundnut (Vigna subterranea L. Verdc.) seed. International Research Journal of Engineering and Technology, 3: 773-782.

17. Kaasik R., Kovács G., Toome M., Metspalu L., Veromann E. 2014. The relative attractiveness of Brassica napus, B. rapa, B. juncea and Sinapis alba to pollen beetles. BioControl, 59 (1): 19-28. https://doi.org/10.1007/s10526-013-9540-0

18. Kocabiyik H., Tezer D. 2007. Determination of thermal properties of rapeseed. Tekirdağ Ziraat Fakültesi Dergisi, 4 (1): $65-70$ (in Turkish). http://dergipark.ulakbim.gov.tr/ jotaf/article/view/5000075167
19. Kurtulmuş F., Ünal H. 2015. Discriminating rapeseed varieties using computer vision and machine learning. Expert Systems with Applications, 42: 1880-1891. https://doi.org/10.1016/j.eswa.2014.10.003

20. Lever T., Haines P., Rouquerol J., Charsley E. L., Van Eckeren P., Burlett D. J. 2014. ICTAC nomenclature of thermal analysis (IUPAC Recommendations 2014). Pure and Applied Chemistry, 86 (4): 545-553. https://doi.org/10.1515/pac-2012-0609

21. Mahapatra A. K., Melton Sh. L., Isang E. M. 2013. Effect of moisture content on thermal properties of cowpea flours. Agricultural Engineering International: CIGR Journal, 15 (2): 251-255.

22. Mailer R. J., Scarth R., Fristensky B. 1994. Discrimination among cultivars of rapeseed (Brassica napus L.) using DNA polymorphisms amplified from arbitrary primers. Theoretical and Applied Genetics, 87 (6): 697-704. https://doi.org/10.1007/BF00222895

23. Mieszkalski L, Żuk Z., Szczyglak P. 2015. Mathematical modeling of the shape of the seed of white mustard (Sinapis alba L.). Postępy Techniki Przetwórstwa Spożywczego, 1: 62-66 (in Polish).

24. OJEC. 2009. Official Journal European Communities. Directive 2009/128/EC of the European Parliament and of the Council of 21 October 2009 establishing a framework for Community action to achieve the sustainable use of pesticides. http://eur-lex.europa.eu/legal-content/EN/TXT/ $\mathrm{PDF} /$ ?uri=CELEX:32009L0128\& from=EN

25. Perussello C. A., Mariani V. C., Masson M. L., de Castilhos F. 2015. Thermophysical properties of yacon (Smallanthus sonchifolius): experimental determination and effect of moisture content. Acta Scientiarum Technology, 37 (1): 167-173. https://doi.org/10.4025/actascitechnol.v37i1.20624

26. Piętka T., Krzymański J., Krótka K., Bartkowiak-Broda I. 2014. Double low white mustard (Sinapis alba L. syn. Brassica hirta) is a source of protein and oil. Rośliny Oleiste / Oilseed Crops, 35: 21-35.

27. Potts D. A., Rakow G. W., Males D. R., Woods D. L. 2003. The development of canola - quality Brassica juncea. Canadian Journal of Plant Science, 83: 117-118.

28. Ropelewska E., Zapotoczny P., Budzyński W. S., Jankowski K. J. 2017. Discriminating power of selected physical properties of seeds of various rapeseed (Brassica napus L.) cultivars. Journal of Cereal Science, 73: 62-67. https://doi.org/10.1016/j.jcs.2016.11.012

29. Sahin S., Sumnu S. G. 2006. Thermal properties of foods. Sahin S., Sumnu S. G. (eds). Physical properties of foods. New York, USA, p. 107-155. https://doi.org/10.1007/0-387-30808-3_3

30. Sangamithra A., Swamy G. J., Prema S. R., Nandini K., Kannan K., Sasikala S., Suganya P. 2016. Moisture dependent physical properties of maize kernels. International Food Research Journal, 23 (1): 109-115.

31. Schuster-Gajzágó I., Vető-Kiszter A., Tóth-Markus M., Baráth A., Márkus-Bednarik Z., Czukor B. 2006. The effect of radio frequency heat treatment on nutritional and colloid-chemical properties of different white mustard (Sinapis alba L.) varieties. Innovative Food Science and Emerging Technologies, 7 (1): 74-79.

32. Sirisomboon P., Posom J. 2012. Thermal properties of Jatropha curcas L. kernels. Biosystems Engineering, 113: 402-409. https://doi.org/10.1016/j.biosystemseng.2012.09.013

33. Talafih K. A., Nasri I., Haddad N. I., Butros I., Hattar B. I., Kharallah K. 2007. Effect of some agricultural practices on the productivity of black cumin (Nigella sativa L.) grown under rainfed semi-arid conditions. Jordan Journal of Agricultural Sciences, 3 (4): 385-397. 
34. Tavakoli H., Rajabipour A., Mohtasebi S. S. 2009 (a). Moisture-dependent some engineering properties of soybean grains. Agricultural Engineering International: the CIGR Ejournal, 11: 1-14.

35. Tavakoli M., Tavakoli H., Rajabipour A., Ahmadi H., Gharib-Zahedi S. M. T. 2009 (b). Moisture-dependent physical properties of barley grains. International Journal of Agricultural and Biological Engineering, 2 (4): 84-91.

36. Waalen W. M., Stavang J. A., Olsen J. E., Rognli O. A. 2014. The relationship between vernalization saturation and the maintenance of freezing tolerance in winter rapeseed. Environmental and Experimental Botany, 106: 164-173. https://doi.org/10.1016/j.envexpbot.2014.02.012

37. Wang J., Carson J. K., North M. F., Cleland D. J. 2008. A new structural model of effective thermal conductivity for heterogeneous materials with co-continuous phases. International Journal of Heat and Mass Transfer, 51: 2389-2397.

https://doi.org/10.1016/j.ijheatmasstransfer.2007.08.028

38. Wilhelm L. R., Suter D. A., Brusewitz G. H. 2004. Physical properties of food materials. Chapter 2. Food and process engineering technology. ASAE, p. 23-53.

https://doi.org/10.13031/2013.17550
39. WRB. 2014. World reference base for soil resources 2014, update 2015. World Soil Resources Reports No. 106. FAO, Rome.

40. Zapotoczny P., Żuk-Gołaszewska K., Ropelewska E. 2016. Discrimination based on changes in the physical properties of fenugreek (Trigonella foenum-graecum L.) seeds subjected to various cultivation conditions. European Food Research and Technology, 242 (3): 405-414. https://doi.org/10.1007/s00217-015-2551-6

41. Zou Q., Fang H., Liu F., Kong W., He Y. 2011. Comparative study of distance discriminant analysis and $\mathrm{Bp}$ neural network for identification of rapeseed cultivars using visible/near infrared spectra. Computer and Computing Technologies in Agriculture IV. IFIP Advances in Information and Communication Technology, 347: 124-133.

https://doi.org/10.1007/978-3-642-18369-0_15

ISSN 1392-3196 / e-ISSN 2335-8947

Zemdirbyste-Agriculture, vol. 105, No. 3 (2018), p. 257-264

DOI $10.13080 / \mathrm{z}-\mathrm{a} .2018 .105 .033$

\title{
Baltụjų garstyčių tradicinès ir 00 tipo veislių sèklų termofizikinès ir cheminès savybès
}

\author{
E. Ropelewska, K. J. Jankowski, P. Zapotoczny, B. Bogucka \\ Varmijos Mozūrų universitetas, Lenkija
}

\section{Santrauka}

Tyrimo tikslas - palyginti baltosios garstyčios (Sinapis alba L.) tradicinės 'Radena' ir 00 tipo 'Warta' veislių sėklų termines, fizikines, mechanines ir chemines savybes. Sèklų terminès savybès buvo analizuotos prietaisu KD2 Pro instrumentu. Palygynus su 'Radena', veislès 'Warta' garstyčių sėklos pasižymėjo didesniu terminiu laidumu $\left(0,126 \mathrm{~W} \mathrm{~m} \mathrm{~m}^{-1} \mathrm{~K}^{-1}\right)$, tūrine šilumine galia $\left(1,448 \mathrm{MJ} \mathrm{m}^{-3} \mathrm{~K}^{-1}\right)$, specifine šilumine galia $\left(1,987 \mathrm{~kJ} \mathrm{~kg}^{-1} \mathrm{~K}^{-1}\right)$ ir mažesne termine varža $\left(793,3^{\circ} \mathrm{C} \mathrm{cm} \mathrm{W}^{-1}\right)$ : terminis laidumas $-0,122 \mathrm{~W} \mathrm{~m}^{-1} \mathrm{~K}^{-1}$, tūinè šiluminè galia $-1,398 \mathrm{MJ} \mathrm{m}^{-3} \mathrm{~K}^{-1}$, specifinè šiluminè galia $-1,850 \mathrm{~kJ} \mathrm{~kg}^{-1} \mathrm{~K}^{-1}$, terminè varža $-820,5^{\circ} \mathrm{C} \mathrm{cm} \mathrm{W}$. Abiejų veislių garstyčių sẻklos pasižymèjo vienoda šilumos difuzija $\left(0,087 \mathrm{~mm}^{2} \mathrm{~s}^{-1}\right)$. Didžiausios pradinių endoterminių pikų vertès ir paskutinis endoterminis pikas buvo nustatyti iš diferencialinių skenavimo kalorimetrijos kreivių. Abiejų veislių garstyčių sẻklų vidutinès bendrujų pikų vertès buvo nustatytos - esant 17,5, 86,0 ir $402,3{ }^{\circ} \mathbf{C}$ ('Warta') ir 16,5, 69,9 ir 400,1 ${ }^{\circ} \mathrm{C}$ ('Radena') temperatūrai. Veislès 'Radena' garstyčių sèklų papildomas pikas atsirado esant $0,8^{\circ} \mathrm{C}$ temperatūrai. Diferencialinių skenavimo kalorimetrinių kreivių plotas buvo $1539 \mathrm{~J} \mathrm{~g}^{-1}$ ('Warta') ir $1847 \mathrm{~J} \mathrm{~g}^{-1}$ ('Radena'). Palyginus su 'Radena', veislès 'Warta' garstyčiu sėklos pasižymèjo mažesniu tūriniu tankiu ir tikruoju tankiu, didesniu poringumu ir didesniais dydžiais. Tūrinis tankis buvo lygus $0,729 \mathrm{~g} \mathrm{~cm}^{-3}$ ('Warta') ir $0,755 \mathrm{~g} \mathrm{~cm}^{-3}$ ('Radena'), tikrasis tūris $1,169 \mathrm{~g} \mathrm{~cm}^{-3}$ ('Warta') ir 1,203 $\mathrm{g} \mathrm{cm}^{-3}$ ('Radena'), poringumas - 37,73\% ('Warta') ir 37,18\% ('Radena'), ilgis - 2,55 mm ('Warta') ir 2,49 mm ('Radena'), plotis - 2,29 mm ('Warta') ir 2,27 mm ('Radena'). Veislès 'Radena' garstyčių sẻklos pasižymėjo didesniu kietumu $(24,7 \mathrm{~N})$, žalių baltymų kiekiu $\left(341,9 \mathrm{~g} \mathrm{~kg}^{-1}\right.$ sausujų medžiagų) ir mažesniu žalių riebalų kiekiu (182,9 $\mathrm{g} \mathrm{kg}^{-1}$ sausujų medžiagų) nei veislès 'Warta': atitinkamai 21,6 N, 315,5 $\mathrm{g} \mathrm{kg}^{-1}$ ir $243,3 \mathrm{~g} \mathrm{~kg}^{-1}$ sausujų medžiagų.

Reikšminiai žodžiai: diferencialinè skenavimo kalorimetrija, cheminès savybès, fizikinès savybès, 'Radena' (tradicinè veislè), Sinapis alba, terminès savybès, termogravimetrinè analizé, 'Warta' (00 tipo veislè). 